\title{
Water Hyacinth Control by Glyphosate Herbicide and Its Impact on Water Quality
}

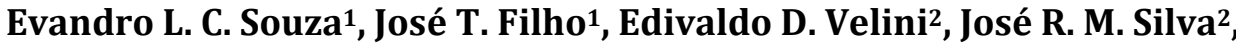 \\ Kelly C. Tonello ${ }^{3}$, Luiz L. Foloni1, Admílson C. Barbosa ${ }^{4}$, Thiago A. Freato ${ }^{5}$
}

${ }^{1}$ School of Agricultural Engineering, State University of Campinas, Campinas, Brazil

${ }^{2}$ Department of Plant Breeding an Protection, College of Agricultural Sciences, Sao Paulo State University, Botucatu, Brazil

${ }^{3}$ Departament of Environmental Sciences, Federal University of São Carlos, Sorocaba, Brazil

${ }^{4}$ Empresa Metropolitana de Águas e Energia S.A. (EMAE), São Paulo, Brazil

${ }^{5}$ Center of Meteorological and Climate Researchers Applied to Agriculture, State University of Campinas, Campinas, Brazil

Email:elcorrea77@hotmail.com

How to cite this paper: Souza, E.L.C. Filho, J.T., Velini, E.D., Silva, J.R.M., Tonello, K.C., Foloni, L.L., Barbosa, A.C. and Freato, T.A. (2020) Water Hyacinth Control by Glyphosate Herbicide and Its Impact on Water Quality. Journal of Water Resource and Protection, 12, 60-73.

https://doi.org/10.4236/jwarp.2020.121004

Received: October 31, 2019

Accepted: January 7, 2020

Published: January 10, 2020

Copyright $\odot 2020$ by author(s) and Scientific Research Publishing Inc. This work is licensed under the Creative Commons Attribution International License (CC BY 4.0)

http://creativecommons.org/licenses/by/4.0/

\begin{abstract}
The aim of this study was to evaluate the herbicide glyphosate under aquatic environment conditions, in a controlled and closed experimental field, in the management of water hyacinth (Eichhornia crassipes) in reservoirs. Twenty reservoirs (polyethylene water tanks) with storage capacity of 1000 liters were used, without water flow and without evapotranspired water replacement (worst case), being 04 for each treatment. The adult plants were placed in the water tanks to provide $90 \%$ surface occupation of the reservoir. Five treatments with four repetitions were considered, being: 1) Reservoir colonized by water hyacinth without control; 2) Reservoir colonized by water hyacinth, controlled by glyphosate; 3) Reservoir colonized by water hyacinth, controlled by freezing; 4) Reservoir without water hyacinth and glyphosate application and 5) Reservoir without water hyacinth and no glyphosate application. The glyphosate herbicide was used at the highest recommended dose, 7.0 L $\cdot \mathrm{ha}^{-1}$ or $3360 \mathrm{~g}$ of acid equivalent per ha, applied using carbon dioxide precision equipment (backpack sprayer), providing a flow rate of $200 \mathrm{~L} \cdot \mathrm{ha}^{-1}$. The water samples were collected at the time of application, $6,12,18$ and 24 hours after application and also at 2, 4, 8, 16, 32 and 64 days after application, in the morning, always at the same time, also between 8 and $9 \mathrm{~h}$. The method used for determination of residues was by high performance liquid chromatography (HPLC) and mass spectrometry with a mass selective detector. Low concentrations of glyphosate and aminomethylphosphonic acid (AMPA) were found in both reservoirs that received application of the product. The half-life of glyphosate in water to the reservoirs with water hyacinth was 11 days and in the reservoirs without water hyacinth was 21 days. The results
\end{abstract}


show a low potential of environmental impact of glyphosate use in the control of water hyacinth in reservoirs.

\section{Keywords}

Eichhornia crassipes, Weed Control, Herbicides, Environmental Impact

\section{Introduction}

Aquatic environments, in general, are formed by a great plant biodiversity, which, in ecologically balanced situation, is essential for the maintenance and development of this ecosystem [1] [2] [3] [4] [5]. In areas under high anthropogenic action, the characteristics of the environment are altered with changes in the original characteristics of the body of water, including the biotic and abiotic segments. Under these conditions, some macrophyte populations develop dense colonizations and prevail over other species [6].

The aquatic plants, like weeds, cause damage to the use of ecosystems, the generation of electricity; navigation; water catchment; agricultural activity; fishing activity; public health; leisure and tourism and environment [7]-[14].

Floating aquatic weeds, in particular water hyacinth, are the ones that cause the most serious damage worldwide. It presents rapid multiplication capacity, large area of photosynthetic tissue in proportion to plant length, large capacity to occupy light-incident sites, as well as independence of substrate conditions due to water flow and plant location [1]. For [15] the floating aquatic macrophyte Eichhornia crassipes is considered one of the biggest problems in the tropics and subtropics water bodies.

With the increasing demand for access, use and values associated with surface water and, on the other hand, the exponential growth of this weed in the aquatic environment, control measures have become necessary [16] [17].

Current methods for controlling these aquatic plants, especially in dams, despite the current impossibility of eliminating the causes of destabilization of aquatic ecosystems are mechanical, biological and chemical. Each has its advantage and disadvantage, but in all cases, there is a need to assess the environmental impact caused by its use [17] [18].

The chemical control of aquatic macrophytes is carried out through herbicides and has been used in different places in the world. Its use is reported by a series of works found in the international literature [14] [18] [19] [20] [21].

In Brazil, the production of knowledge in this area has been small, considering the prohibitive legislation of on-site studies [18]. Due to this prohibition, studies conducted in the country have been carried out in controlled environments and in closed systems [11] [14] [20] [21] [22] [23].

The most widely used herbicides worldwide for aquatic macrophyte control are: 2,4-D; diquat; endothal, copper based compound; fluridone; imazapyr and 
glyphosate [22] [24].

Due to the fragility of ecosystems and the fact that chemicals have different toxicities to various organisms in the aquatic ecosystem, careful evaluation is required before proposing the use of any of these substances.

Aiming to evaluate the herbicide glyphosate in aquatic environment, it was chosen to study it in a controlled and closed experimental field, in the management of water hyacinth (Eichhornia crassipes) in reservoirs. The effect of control on water quality and product half-life was analyzed to contribute to the formulation of risk analysis of the environmental impact of the use of this product on aquatic weed control.

\section{Material and Methods}

The study is developed in the Experimental Area of the Faculty of Agricultural Engineering/UNICAMP, from July 2018 to January 2019.

Twenty reservoirs (polyethylene water tanks) with storage capacity of $1000 \mathrm{li}$ ters were used, without water flow and without evapotranspired water replacement (worst case), being four treatment and five plots. The water that supplied the reservoirs came from the abstraction of water from the FEAGRI experimental field.

The herbicide was applied on July 5, 2018. The glyphosate herbicide was used according to the recommendation of the commercial product Glyphosate Transorb, which contains in its formulation $480 \mathrm{~g} \cdot \mathrm{L}^{-1}$ of acid equivalent. The maximum recommended dose, $7.0 \mathrm{~L} \cdot \mathrm{ha}^{-1}$ or $3360 \mathrm{~g}$ of acid equivalent per ha, was used, following the indication for environmental impact studies.

The treatments that received the product were applied using carbon dioxide precision equipment (backpack sprayer), equipped with a compensated bar, containing four flat jet nozzles Jacto XR 110.02, working at a pressure of 2 $\mathrm{kgf} \cdot \mathrm{cm}^{-2}(20 \mathrm{Kpa})$ and providing a grout consumption equivalent to $200 \mathrm{~L} \cdot \mathrm{ha} \mathrm{a}^{-1}$. The calibration was performed on site based on the applicator speed in relation to the worked area. The climatic conditions at the time of application were: ambient temperature of $22^{\circ} \mathrm{C}$, relative humidity of $60 \%$ and wind speed of $0-2$ $\mathrm{km} \cdot \mathrm{h}^{-1}$. The application started at $9 \mathrm{~h}$ and the end at $9 \mathrm{~h} \mathrm{30}$. The chosen time was due to the non-occurrence of wind at the time of application, in order to avoid drift from the syrup to the other reservoirs.

The death of macrophyte by using freezing was the method chosen so that plants preserved their nutritional characteristics and that only nutrients could be released into the environment after the plants returned to their reservoirs. The death of macrophyte by freezing was achieved by storing the plants in a freezer at $-18^{\circ} \mathrm{C}$ for a period of 48 hours. After this period, they were left beside their tanks for a period of 24 hours to thaw. Thus, finishing the process, which corresponded to the same day of herbicide application, were then accommodated in the respective water tanks.

To determine glyphosate residues in water, samples were collected between 15 
and $20 \mathrm{~cm}$ below the water depth at the time of application, 6, 12, 18 and 24 hours after application and also at 2, 4, 8, 16, 32 and 64 days after application, in the morning, always at the same time, also between 8 and $9 \mathrm{~h}$. After each collection, the samples were stored in a freezer at $-18^{\circ} \mathrm{C}$ for subsequent residue analysis.

The concentrations $\left(\mathrm{ng} \cdot \mathrm{L}^{-1}\right)$ of glyphosate and AMPA (glyphosate major metabolite) residues were determined. The method used was high performance liquid chromatography (HPLC) and mass spectrometer with selective mass detector, with detection limit of $0.001 \mathrm{mg} \cdot \mathrm{kg}^{-1}$ for glyphosate.

The mathematical model of decay was applied to describe the decrease in glyphosate concentrations and charges in water and the determination of the half-life of the compounds, according to Equation (1):

$$
M_{t}=M_{0} \cdot \mathrm{e}^{-k t}
$$

where: $M_{t}=$ glyphosate concentration at moment $\mathrm{t} ; M_{0}=$ glyphosate concentration at the initial time considered; $k=$ decay coefficient and $t=$ time.

Applying the Napierian logarithm in Equation (1) gives Equation (2), where:

$$
\ln M_{t}=\ln M_{0}-k t
$$

This equation represents a linear model where the coefficient $(\mathrm{K})$ identifies the decay of glyphosate charge over time. As four reservoirs were used in the experiment, the mean load at the considered times of the samples was calculated to determine the average value of decay for glyphosate.

\section{Results and Discussion}

\subsection{Concentration $\left(\mu \mathrm{g} \cdot \mathrm{L}^{-1}\right)$ of Glyphosate and AMPA in Water}

\subsubsection{Glyphosate}

Figure 1(a) and Figure 1(b) show the average values observed for glyphosate concentration $\left(\mu \mathrm{g} \cdot \mathrm{L}^{-1}\right)$ found in reservoirs with water hyacinth colonization that received herbicide application in the periods after application. Figure 1(a) contemplates the entire period observed and Figure 1(b), until the eighth day to facilitate the understanding of the initial analyzes. Similarly, Figure 2(a) and Figure 2 (b) show the average values of residues found for reservoirs without water hyacinth colonization.

The concentration of glyphosate found in the waterless reservoirs, right after application, was higher when compared to the reservoirs that contained the plant, being about twice as high. However, over time, the levels found in non-planted reservoirs matched those of planted reservoirs. From 32 days after application, the concentrations found in the reservoirs without water hyacinth were lower compared to the reservoir with plant.

The results are similar to those found by [25], showing that from glyphosate metabolization and subsequent plant control or death effectiveness, the decomposition process of dead plants released the product in the reservoir water keeping the contents, even if low, but superior to the reservoirs that received direct 
application of the product.

The results also corroborate the work of [26], who conducted a study to investigate and document the occurrence, fate and transport of glyphosate, its degradation product, aminomethylphosphonic acid and glufosinate in soil samples, surface water, groundwater and rainfall for six years (2001-2006). In the various
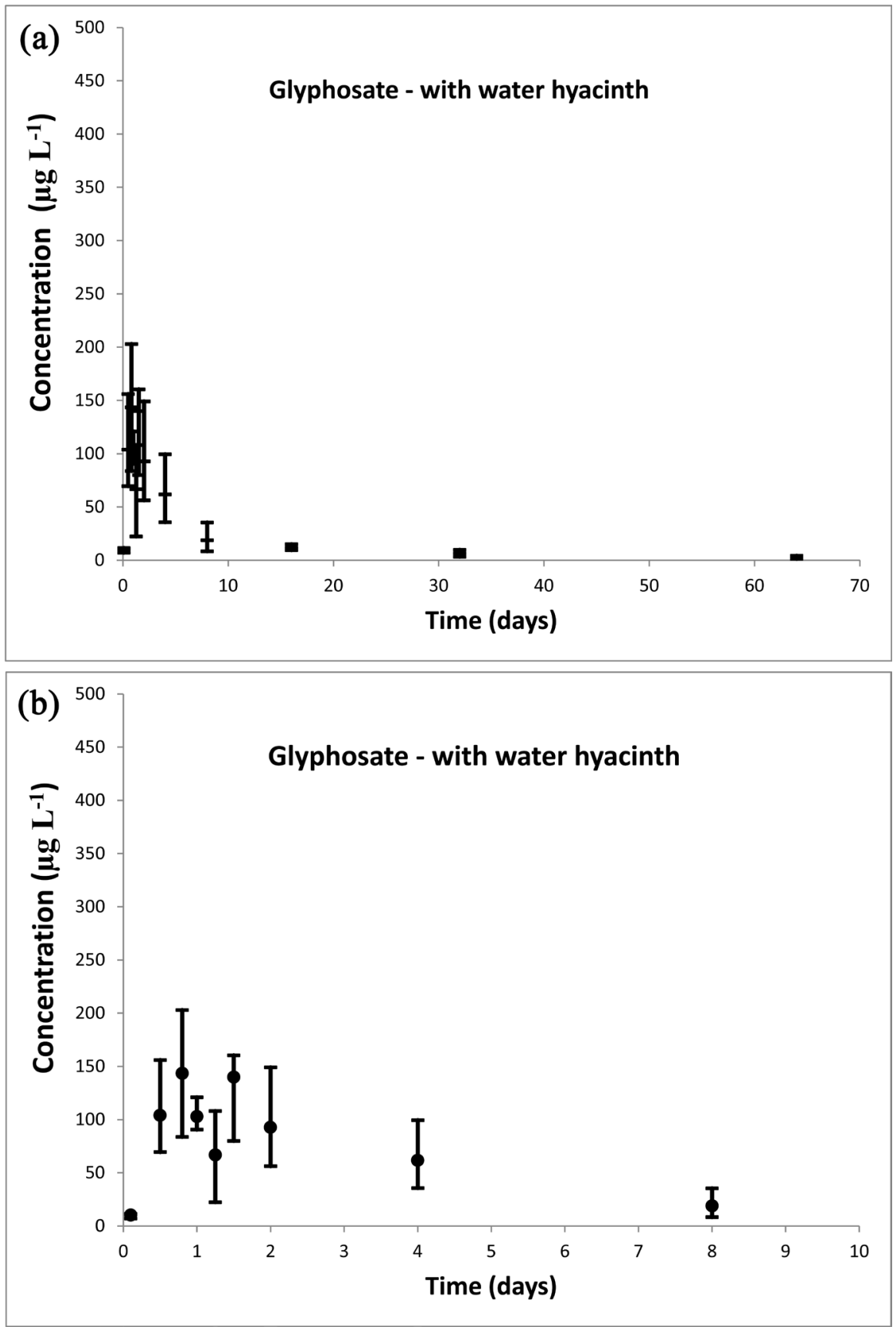

Figure 1. (a) Concentration $\left(\mu \mathrm{g} \cdot \mathrm{L}^{-1}\right)$ of glyphosate in reservoirs with Eichhornia crassipes and application of glyphosate herbicide (CPCG) at 0,6,12, 18 and 24 hours and at 2, 4, 8, 16, 32 and 64 days after application; (b) Concentration $\left(\mu \mathrm{g} \cdot \mathrm{L}^{-1}\right)$ of glyphosate in reservoirs with Eichhornia crassipes and application of glyphosate herbicide (CPCG) at 0, 6, 12, 18 and 24 hours and at 2, 4 and 8 days after application. 

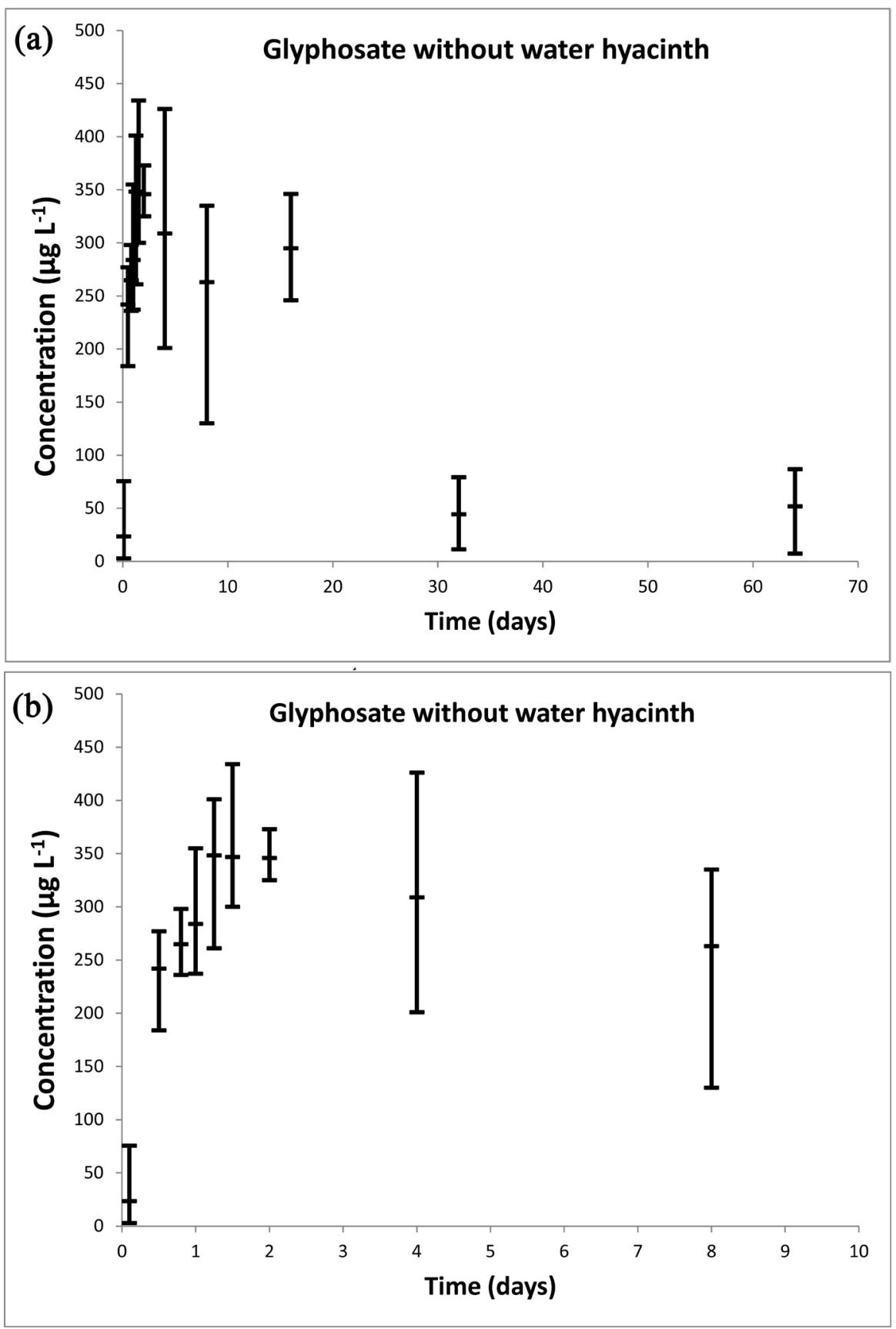

Figure 2. (a) Concentration $\left(\mu \mathrm{g} \cdot \mathrm{L}^{-1}\right)$ of glyphosate in reservoirs without Eichhornia crassipes and glyphosate (SPCG) application at 0, 6, 12, 18 and 24 hours and at 2, 4, 8, 16, 32 and 64 days after the app; (b) Concentration $\left(\mu \mathrm{g} \cdot \mathrm{L}^{-1}\right)$ of glyphosate in reservoirs without Eichhornia crassipes and glyphosate (SPCG) application at 0,6, 12, 18 and 24 hours and at 2, 4 and 8 days after application.

analyzes performed to identify glyphosate residue in surface water samples, the maximum concentration found was $427 \mu \mathrm{g} \cdot \mathrm{L}^{-1}$, similar to the treatment without water hyacinth.

In addition, [27] conducted a study in the United States to evaluate the occurrence of glyphosate and AMPA in soils in surface and groundwater. The re- 
search was carried out between 2001 and 2010, covering 3732 samples in 38 states. Regarding water resources, the results showed lower maximum glyphosate concentrations for groundwater $\left(2.03 \mu \mathrm{g} \cdot \mathrm{L}^{-1}\right)$, rainwater $\left(2.50 \mu \mathrm{g} \cdot \mathrm{L}^{-1}\right)$ and large rivers $\left(3.08 \mu \mathrm{g} \cdot \mathrm{L}^{-1}\right)$ and higher maximum concentrations for streams (73 $\left.\mu \mathrm{g} \cdot \mathrm{L}^{-1}\right)$ and lakes, lagoons and wetlands $\left(301 \mu \mathrm{g} \cdot \mathrm{L}^{-1}\right)$. These results are similar to those found in both treatments of the present experiment. [28] states that glyphosate dissipation is faster where there is water flow than in ponds or reservoirs, due to the mixing action of running water. Because water flow contains a higher oxygen content and microbial activity is generally higher, the result is faster dissipation.

\subsubsection{AMPA}

Figure 3(a) and Figure 3(b) show the average observed values of AMPA concentration $\left(\mu \mathrm{g} \cdot \mathrm{L}^{-1}\right)$ found in reservoirs with water hyacinth colonization that received herbicide application in the periods after product application. Figure 3(a) shows all observed period and Figure 3(b), until the eighth day to facilitate the understanding of the initial analyzes. Similarly, Figure 4(a) and Figure 4(b) show the average values of residues found for reservoirs without water hyacinth colonization.

In the analysis of the AMPA parameter the same behavior of the concentration obtained for glyphosate was expected, that is, higher contents in the reservoirs without the presence of the plant. But, as can be observed, the largest charges were found in the treatment containing the water hyacinth that received the application of the product. However, over time, at 64 days after treatment, both conditions showed low AMPA acid residue, with values close to $2 \mathrm{ng} \cdot \mathrm{L}^{-1}$.

For this behavior it is suggested that the metabolization of AMPA by the bioaccumulation process is superior to glyphosate. The results corroborate those found by [25], who evaluated this parameter in the control of glyphosate water hyacinth and observed low acid residues at 64 days after application of the product. During this period, the values for AMPA residues were about $1.00 \mathrm{mg} \cdot \mathrm{Kg}^{-1}$ in the reservoirs with macrophyte and $0.20 \mathrm{mg} \cdot \mathrm{Kg}^{-1}$ in the reservoirs containing only the herbicide.

In the studies performed by [29] evaluations were performed to detect AMPA. The values in the analyses were also low, between 0.04 and $0.01 \mathrm{mg} \cdot \mathrm{Kg}^{-1}$ up to 31 days after application. After this period, no AMPA residues were detected in the water. Also, [27] found low levels of AMPA in surface waters, namely: rivers $\left(4.43 \mu \mathrm{g} \cdot \mathrm{L}^{-1}\right)$ and streams $\left(28 \mu \mathrm{g} \cdot \mathrm{L}^{-1}\right)$.

In the research by [26], the maximum value obtained for aminomethylphosphonic acid in surface water samples was $29 \mu \mathrm{g} \cdot \mathrm{L}^{-1}$, close to those found in the present research (below $35 \mu \mathrm{g} \cdot \mathrm{L}^{-1}$ ). On the other hand, the researchers found AMPA levels similar or higher than Glyphosate. Additional studies also showed that glyphosate and AMPA were detected more often in surface waters than in groundwater. These data report the importance of analyzing not only glyphosate but also AMPA in water quality studies. 

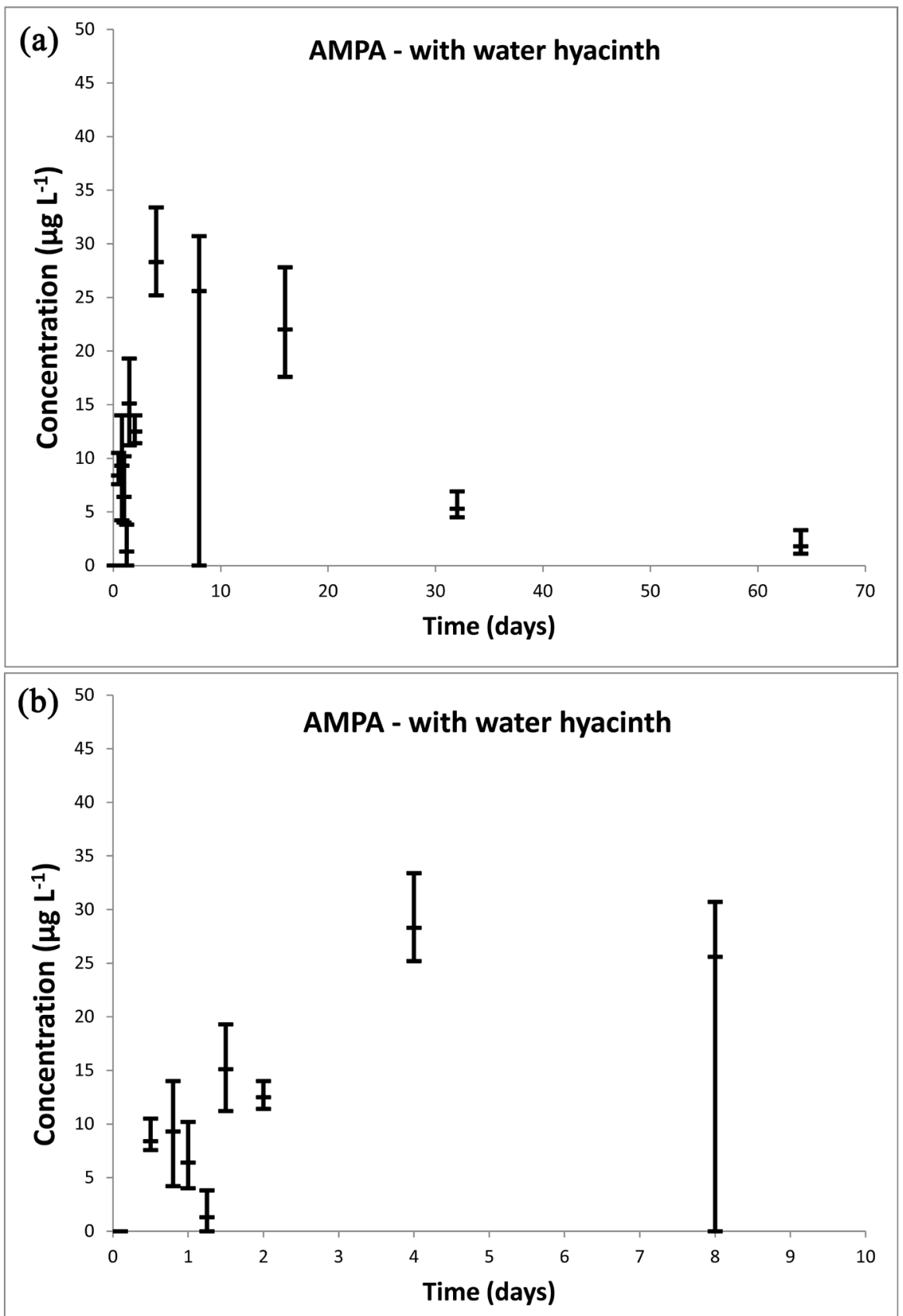

Figure 3. (a) AMPA concentration $\left(\mu \mathrm{g} \cdot \mathrm{L}^{-1}\right)$ in Eichhornia crassipes reservoirs and Glyphosate (CPCG) application at 0, 6, 12, 18 and 24 hours and at 2, 4, 8, 16, 32 and 64 days after the app; (b) AMPA concentration $\left(\mu \mathrm{g} \cdot \mathrm{L}^{-1}\right)$ in the Eichhornia crassipes reservoirs and glyphosate (CPCG) application at $0,6,12,18$ and 24 hours and at 2, 4, and 8 days after application.

\subsection{Glyphosate Half Life in Water}

To obtain this value, the logarithm (Ln) was applied to the observed charge values to obtain Figure 5.

As observed in Figure 5, a linear model was fitted in which the value of the angular coefficient represents the value of decay. The value found for the decay 
coefficient in Figure 5 was 0.0572 day $^{-1}$ (for the plant and glyphosate application reservoir).

From the value found in the average load of glyphosate decay coefficient, the mean glyphosate values are simulated using the mathematical model of equation 1. Following the model, it was possible to estimate the half-life of glyphosate in
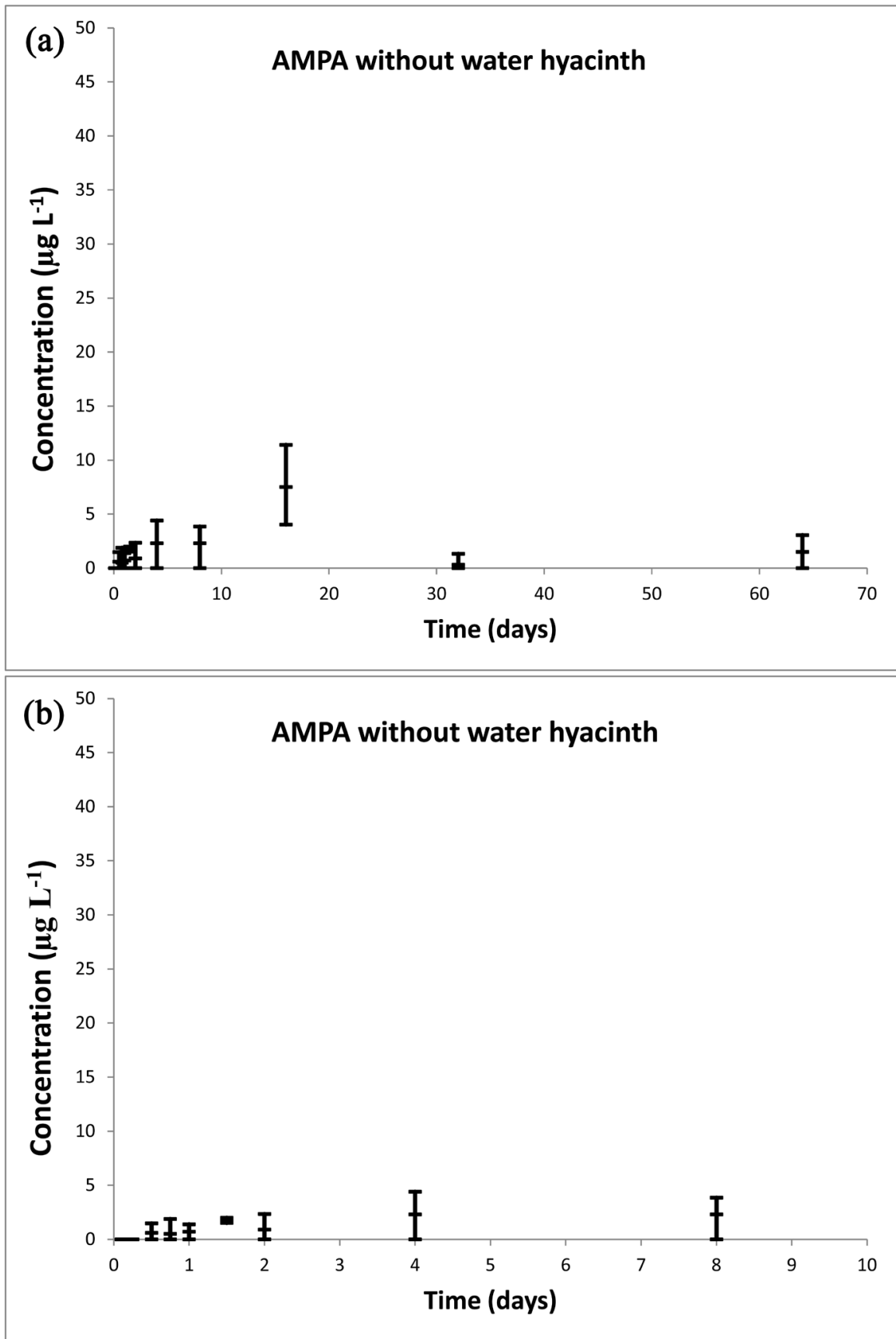

Figure 4. (a) AMPA concentration $\left(\mu \mathrm{g} \cdot \mathrm{L}^{-1}\right)$ in the reservoirs without Eichhornia crassipes and glyphosate application (SPCG) at 0, 6, 12, 18 and 24 hours and at 2, 4, 8, 16, 32 and 64 days after the application; (b) AMPA concentration $\left(\mu \mathrm{g} \cdot \mathrm{L}^{-1}\right)$ in reservoirs without Eichhornia crassipes and glyphosate (SPCG) application at 0,6,12, 18 and 24 hours and at 2, 4 and 8 days after application. 
water for treatment with macrophyte. Considering the estimated average load, the half-life was 11 days.

In the same way the simulation was made for the reservoirs that did not received the colonization of the water hyacinth. The coefficient $\mathrm{K}$ value and the observed and simulated mean load values are shown in Figure 6.

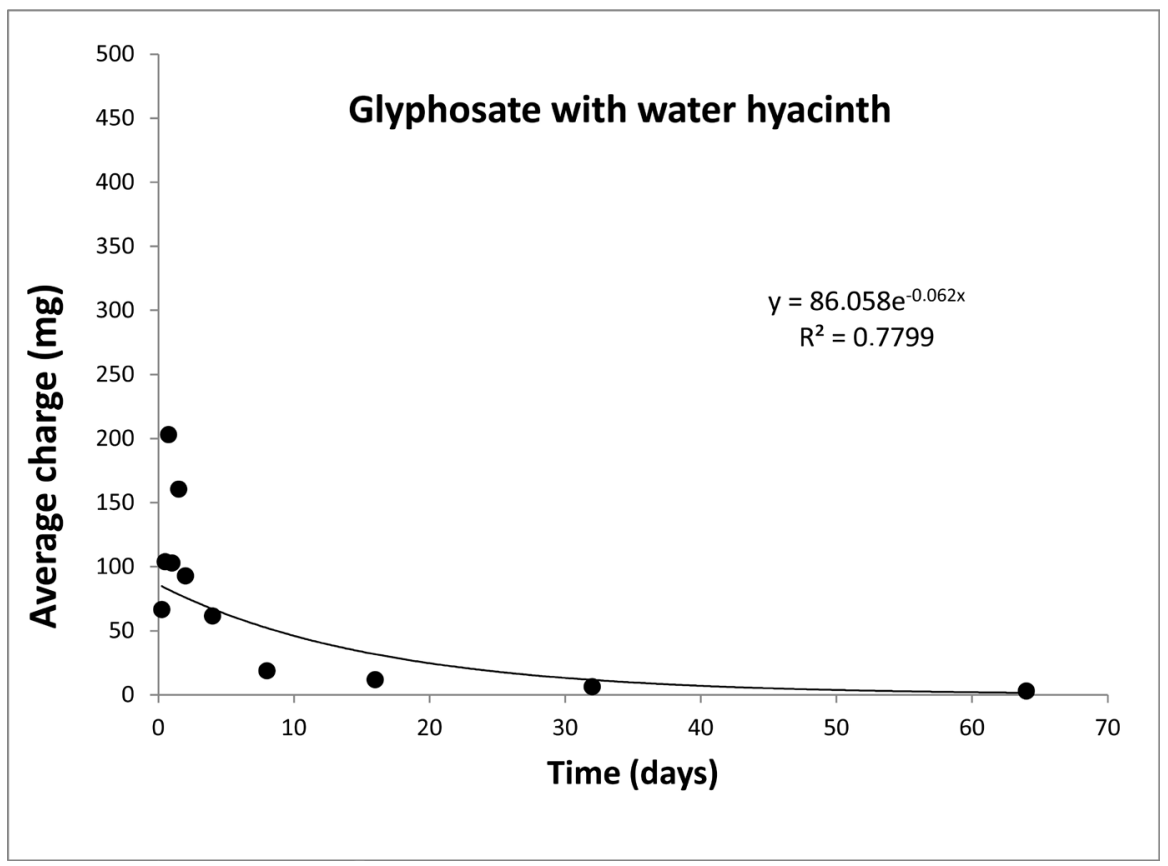

Figure 5. Ln of the average glyphosate charge in water as a function of time. Reservoir with plant and glyphosate application.

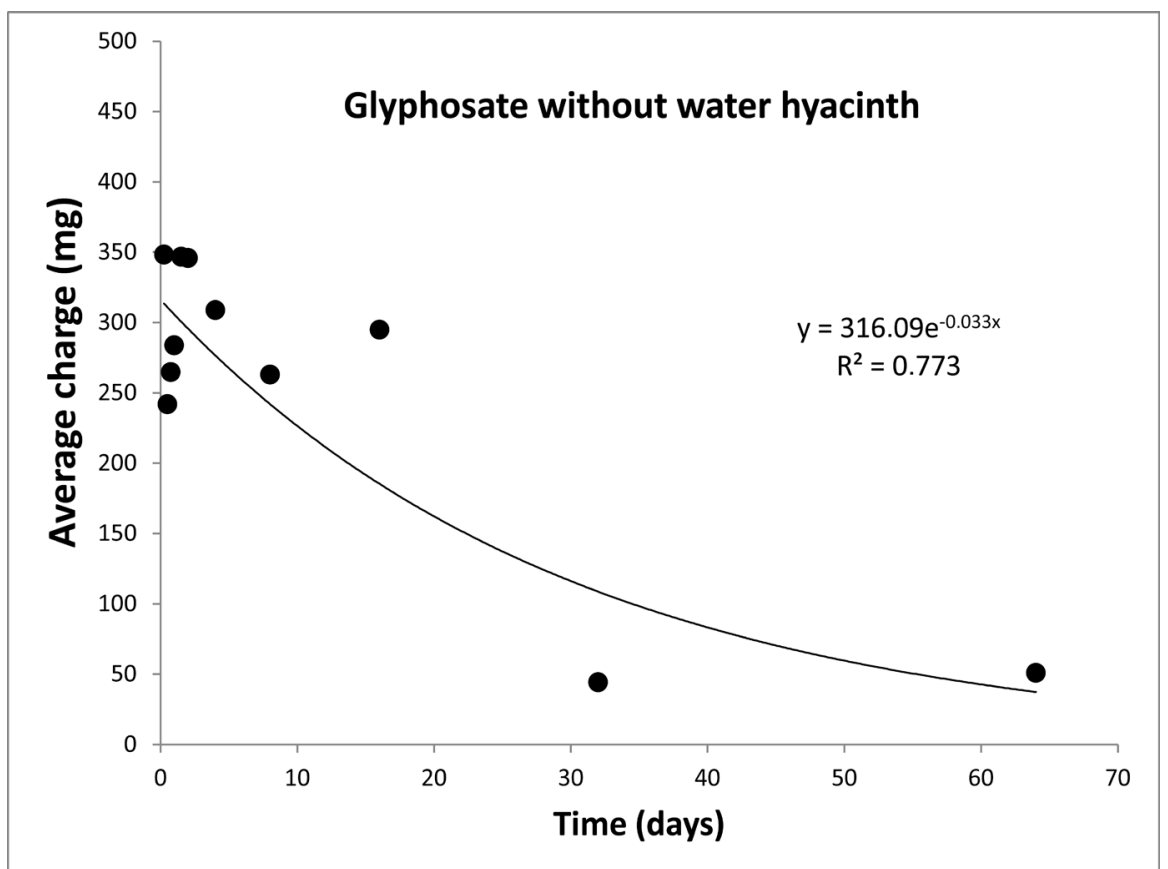

Figure 6. Ln of the average glyphosate charge in water as a function of time. Reservoir without plant and glyphosate application. 
Glyphosate half-life in water was estimated for treatment without macrophyte. Considering the average load, the half-life was 21 days.

The simulated values for glyphosate half-life in water, in both situations, are in agreement with [30] who reports that the average molecule life in water can reach 21 days and with [31], who claim that depending on water body conditions, especially those linked to full microbial activity, can range from a few days to two weeks.

Studies conducted in a forest ecosystem [32] [33] showed that glyphosate dissipated rapidly in the water of many suspended sediment ponds, with a half-life ranging from 1.5 to 11.2 days.

Also, in the work developed by [34], whose water body was a river (open system), it was observed that the glyphosate half-life in this environment varied between 60 and 100 hours.

Studies on glyphosate degradation report the importance of microorganism activity in the metabolism of this compound. Chemical degradation and photodecomposition appear to be secondary routes to glyphosate breakdown. Glyphosate is completely degraded in CO by microorganisms in water [35] [36].

\section{Conclusions}

The study has shown that low concentrations of glyphosate and aminomethylphosphonic acid (AMPA) were found in both reservoirs that received application of the product.

The half-life of glyphosate in water to the reservoirs with water hyacinth was 11 days and in the reservoirs without water hyacinth was 21 days.

The results show that a low potential of environmental impact of glyphosate use in the control of water hyacinth in reservoirs, can be recommended for use in continuous flow aquatic environments as there is greater herbicide dissipation and degradation in this ambient.

\section{Acknowledgements}

We thank the National Electric Energy Agency (ANEEL) for funding the research, as well as the Metropolitan Water and Energy Company (EMAE), the Brvant Institute of Research and Development (IBRV), the State University of Campinas and the Weed Science Center (NUPAM) of the College of Agricultural Sciences of Sao Paulo State University for generous support in this project.

\section{Conflicts of Interest}

The authors declare no conflicts of interest regarding the publication of this paper.

\section{References}

[1] Instituto Brasileiro do Meio Ambiente e Dos Recursos Naturais Renováveis-IBAMA (2001) Workshop Controle de plantas aquáticas. IBAMA, Brasília. 
[2] Tanaka, R.H. (1998) Prejuízos provocados pelas plantas aquáticas. In: Workshop Controle de Plantas Aquáticas, IBAMA, Brasília, 36-38.

[3] Asaeda, T., Trung, V.K. and Mantunge, J. (2000) Modeling the Effects of Macrophyte Growth and Decomposition on the Nutrient Budget in Shallow Lakes. Aquatic Botany, 68, 217-237. https://doi.org/10.1016/S0304-3770(00)00123-6

[4] Velini, E.D., Negrisoli, E., Cavenaghi, A.L., Correa, M.R., Bravin, L.F.N., De Marchi, S.R., Trindade, M.L.B., Arruda, D.P. and Padilha, F.S. (2005) Characterization of Water and Sediment Quality at the Americana Reservoir Related to the Occurrence of Aquatic Plants. Planta Daninha, 23, 215-223. https://doi.org/10.1590/S0100-83582005000200007

[5] Foloni, L.L. (2008) Impacto ambiental de herbicidas no meio aquático. In: Congresso Brasileiro da Ciência das Plantas Daninhas, Resumos, SBCPD, Ouro Preto, 107-114.

[6] Pitelli, R.A. (2009) Uso do glyphosate no controle de macrófitas aquáticas. In: Velini, E.D., Meschede, D.K., Carbonari, C.A. and Trindade, M.L.B., Eds., Glyphosate, Fepaf, Botucatu, 413-427.

[7] Marcondes, D.A.S. and Tanaka, R.H. (1997) Plantas aquáticas nos reservatórios das usinas hidrelétricas da CESP. In: Congresso Brasileiro das Ciências das Plantas Daninhas, SBCPD, Viçosa, 2-4.

[8] Pitelli, R.A. (1998) Macrófitas aquáticas no Brasil, na condição de problemáticas. In: 1998 Workshop Controle de Plantas Aquáticas, Instituto Brasileiro de Meio Ambiente e dos Recursos Naturais Renováveis, Brasília, 12-15.

[9] Smith, V.H., Tilman, G.D. and Nekola, J.C. (1999) Eutrophication: Impacts of Excess Nutrient Inputs on Freshwater, Marine, and Terrestria Ecosystems. Environmental Pollution, 100, 176-196. https://doi.org/10.1016/S0269-7491(99)00091-3

[10] Van Nes, E.H., Scheffer, M., Van Den Berg, M. and Coops, H. (2002) Aquatic Macrophytes: Restore, Erradicate or Is There a Compromise? Aquatic Botany, 72, 387-403. https://doi.org/10.1016/S0304-3770(01)00212-1

[11] Tanaka, R.H., Cardoso, L.R., Martins, D. and Marcondes, D.A.S. (2002) Aquatic Weed Survey in Reservoirs Controlled by the Oower Plant of São Paulo, Brazil. Planta Daninha, 20, 101-111. https://doi.org/10.1590/S0100-83582002000400012

[12] Thomaz, S.M. (2002) Ecological Factors Associated to Aquatic Macrophyte Colonization and Growth and Management Challenges. Planta Daninha, 20, 21-33. https://doi.org/10.1590/S0100-83582002000400003

[13] Cavenaghi, A.L., Velini, E.D., Negrisoli, E., Carvalho, F.T., Galo, M.L.B.T., Trindade, M.L.B., Correa, M.R. and Santos, S.C.A. (2005) Monitoring Problems with Aquatic Plants and Characterization of Water and Sediment Quality at UHE Mogi-Guaçu. Planta Daninha, 23, 225-231. https://doi.org/10.1590/S0100-83582005000200008

[14] Martins, D., Costa, N.V., Terra, M.A. and Marchi, S.R. (2008) Characterization of the Aquatic Plant Communities of 18 Reservoirs of Five Watersheds in Sao Paulo, Brazil. Planta Daninha, 26, 17-32. https://doi.org/10.1590/S0100-83582008000100003

[15] Labrada, R. (1995) Status of Water Hyacinth in Developing Countries. In: Labrada, R., Charudattan, R., Center, T.D. and Kelly-Begazo, C., Eds., Strategies for Water Hyacinth Control Report of a Panel of Experts Meeting, FAO, Rome, 3-11.

[16] Velini, E.D., Galo, M.L.B.T., Trindade, M.L.B., Martins, D. and Bronhara, A.A. (2002) Manejo de plantas aquáticas em grandes reservatórios: Riscos associados a estratégia de não ação. In: 2002 Congresso Brasileiro Da Ciência Das Plantas 
Daninhas, SBCPD/Embrapa-Clima Temperado, Londrina, 610.

[17] Velini, E.D. (2008) Monitoramento, controle mecânico e técnicas para o controle químico. Faculdade de Ciências Agronômica/UNESP, Botucatu.

[18] Pitelli, R.A., Martins, D. and Velini, E.D. (2008) Interferências e controle de macrófitas aquáticas. In: Vargas, L. and Roman, E.S., Eds., Manual de manejo e controle de plantas daninhas, HRAC-BR, Passo Fundo, 299-328.

[19] Chikura, S. (1986) Chemical Control of Aquatic Weeds. In: Ecology and Management of Aquatic Weeds, Weed Science Society of Japan, Tokyo, 97-110.

[20] Cícero, E.A.S., Pitelli, R.A., Sena, J.A.D. and Ferraudo, A.S. (2007) Genetic Variability and Sensitivity of Pistia Stratiotes Accesses to Glyphosate. Planta Daninha, 25, 579-587. https://doi.org/10.1590/S0100-83582007000300018

[21] Guimarães, G.L. (2003) Impacts of Macrophytes Control Using 2,4-D Herbicide on Mesocosms. Doctoral Thesis, Faculty of Agricultural Engineering, State University of Campinas, Campinas.

[22] Martins, D. (1998) Controle de plantas daninhas aquáticas. In: 1998 Workshop Controle De Plantas Aquáticas, IBAMA, Brasília, 30-31.

[23] Martins, D., Velini, E.D., Costa, N.V., Cardoso, L.A. and Souza, G.S.F. (2011) Chemical Control of Eichhornia crassipes and Brachiaria subquadripara with Diquat under Reservoir Conditions. Planta Daninha, 29, 51-57. https://doi.org/10.1590/S0100-83582011000100006

[24] Villamagna, A. and Murphy, B. (2010) Ecological and Socio-Economic Impacts of Invasive Water Hyacinth (Eichhornia crassipes): A Review. Freshwater Biology, 5, 282-298. https://doi.org/10.1111/j.1365-2427.2009.02294.x

[25] Souza, E.L.C., Foloni, L.L., Filho, J.T., Velini, E.D., Siono, L.M. and Silva, J.R.M. (2017) Half-Life of Glyphosate on the Control of Water Hyacinths in Water Tanks. Journal of Water Resource and Protection, 9, 470-481. https://doi.org/10.4236/jwarp.2017.95030

[26] Scribner, E.A., Battaglin, W.A., Gilliom, R.J. and Meyer, M.T. (2007) Concentration of Glyphosate, Its Degradation Product, Aminomethylphosphonic Acid and Glufosinat in Ground and Surface Water, Rainfall, and Soil Samples Collected in the United States, 2001-2006. https://www.usgs.gov https://doi.org/10.3133/sir20075122

[27] Battaglin, W.A., Meyer, M.T., Kuivila, K.M. and Dietze, J.E. (2014) Glyphosate and Its Degradation Product AMPA Occur Frequently and Widely in U.S. Soils, Surface Water, Groundwater, and Precipitation. Journal of the American Water Resources Association, 5, 275-290. https://doi.org/10.1111/jawr.12159

[28] Lancar, L. and Krake, K. (2002) Aquatic Weeds \& Their Management. International Commission on Irrigation and Drainage, ICID, 71p.

[29] Tsui, M.T.K. and Chu, L.M. (2007) Environmental Fate and Non-Target Impact of Glyphosate-Based Herbicide (Roundup) in a Subtropical Wetland. Chemosphere, 71, 439-446. https://doi.org/10.1016/j.chemosphere.2007.10.059

[30] Paterson, M. (2004) Glyphosate Analisis of Risks to Endangered and Threatened Salmon and Steelhead. http://www.epa.gov/espp/litstatus/effects/glyphosate-analysis.pdf

[31] Giesy, J.P., Dobson, S. and Solomon, K.R. (2000) Ecotoxicological Risk Assessment for Roundup Herbicide. Reviews of Environmental Contamination and Toxicology, 167, 35-120. https://doi.org/10.1007/978-1-4612-1156-3_2

[32] Feng, J.C., Thompson, D.G. and Reynolds, P.E. (1990) Fate of Glyphosate in a Ca- 
nadian Forest Watershed. 1. Aquatic Residues and Off Target Deposit Assessment. Journal of Agricultural and Food Chemistry, 38, 1110-1118. https://doi.org/10.1021/jf00094a045

[33] Goldsborough, L.G. and Brown, D.J. (1993) Dissipation of Glyphosate and Aminomethylphosphonic Acid in Water and Sediments of Boreal Forest Ponds. Environmental Toxicology and Chemistry, 12, 1139-1147.

https://doi.org/10.1002/etc.5620120702

[34] Mallat, E. and Barceló, D. (1998) Analysis and Degradation Study of Glyphosate and of Aminomethylphosphonic Acid in Natural Waters by Means of Polymeric and Ion-Exchange Solid-Phase Extraction Columns Followed by Ion Chromatography-Post-Column Derivatization with Fluorescence Detection. Journal of Chromatography, 823, 129-136. https://doi.org/10.1016/S0021-9673(98)00362-8

[35] Bronstad, J.O. and Friestad, H.O. (1985) Behaviour of Glyphosate in the Aquatic Environment. In: Grossbar, E. and Aktinson, D., Eds., The Herbicide Glyphosate, Butterworks, London, 200-205.

[36] Veiga, F., Zapata, J.M., Fernandez, M.M.L. and Alvarez, E. (1999) Degradation of Herbicides Glyphosate and Glufosinate in Natural and Distilled Water. In: Bech, J., Ed., Soils with Mediterranean Type of Climate, Novoprint, Oconomowoc, WI, 161-163. 